\title{
Die ekologiese relevansie van chemiese stres op die "gesondheid" van die biologiese omgewing
}

\author{
A.J. Reinecke \\ Departement Soölogie, Universiteit van Stellenbosch, Privaat sak XI, Maticland, 7602 \\ ajr@maties.sun.ac.za
}

Onriang + Maarl 1998; aumvaar 4 Augustus 1998

\section{UITTREKSEL}

Die begrip "omgewingsgesondheid" word soms verwarrend gebraik en kan sowel na die "welstand" of optimale finksionering van die natuurlike ongewing of ekostelsels verwys as na die kwaliteit van die ongewing met betrekking tot menslike gesondlheid. Ekostelse/s is nie organismies van aard nie en daar is nie homeostatiese patrone wat deur' 'n sentrale genetiese kern of "genotiep" bepal word nie. Ekostelsels verander voortdurend. Evolusie en die geskiedenis van spesiasie dhi eerder op 'n chaotiese stelsel wat nie noodwendig na die vorige toestand sal herstel nadat chemiese drukfaktore opgehef word nie. Getuienis word angebied dat bevolkings van spesies fisiologies en geneties by toestande van omgewingsbesoedeling kan aanpas. Sensitiewe spesies word norma biodiversiteit afneem met gevolg/ike onomkeerbare verandering in die strukturele en funksionele eienskappe van gemeenskappe. Die ekologiese relevansie van chemiese impak op die omgewing word toenemend op molekulêre vlak gesoek. 


\section{Anstract}

\section{The ecological relevance of chemical stress on the "health" of the biological environment}

The term "environmental heath" is frequenty and confusingly wsed to refer both to the "healh" or optimal functioning of the natural environment or ecosystems and also to the quality of the enviromment for human health. Ecosystems are by nature not organismic and there are no homeostatic patterns that are controlled by a central genetic nucteas or "genotype". Ecosystems are continuously changing. Evolution and the history of speciation rather point to a chatic system which will not necessarily return to the previous state once" chemical stressors are removed. Evidence is presented to show that populations of species andergo physiological and gene tic adaptation under conditions of environmental pollution. Sensitive species are normally lost with a resulting loss in biodiversity and change in the finctional and stractural characteristics of a community. The ecological relevance of chemical impacts on the enviromment are increasingly sough at the molecular level.

\section{INLEIDING}

Die moderne samelewing het toenemend afhanklik geword van chemikalicë wat dikwels in dic natuurlike omgewing beland waar dit skadelike clfekte tol gevolg kan hê. Ons welenskaplike vermoë om dic moonllike elfektc wat sulke slowwe op ckostelsels mag hê, te voorspel, het nic tred gehou met hicrdic groeiende chemiese arsenaal nic. Hoewel analitiese tegnicke om die tcenwoordigheid van chemiese stowwe in dic natuurlike omgewing te kwaliliseer en te kwantiliseer voortdurend verbeter en ons in staat stel om akkurate metings daarvan te neem, is dit nie voldoende nic. Kennis van die hoeveclheid en soort stol in die omgewing gee nic noodwendig antwoorde oor die stol se biologiese beskikbaarheid nic. Hocwel die stol dus tecnwoordig mag wees, sal die toksiese clfckte stecds afhang van dic werklike blootstelling en opname deur die organismes. Gevolglik is dic daarstelling van "veilige" konsentrasies van 'n omgewingskontaminant problematies, ook omdat sommige organismes sclf stowwe kan regulece. Die problecm word vererger deur dic verskynsel dat organismes sommige stowwe kan akkumulecr sonder om self daardeur gealifektecr te word. Wannecr hicrdic organismes as prooi van sensitiewe predatore sou dien, kan dil crnstige implikasies vir die predator inhou. In die assessering van die omgewingsrisiko van 'n chemiese stof moet daar dus met verskeic biologiese laktore rekening gehou word. Dit gaan uitcindelik ook nie oor dic beskerming van dic individucle organisme nic, maar oor dic beskerming van ckostelsels as gehecl. En die vraag wat na vore kom, is of 'n chemiese stof' se uitwerking ekologiese implikasies het en hoe dit bepaal kan word.

'n Toenemende bewuswording deur die mensdom dat 'n "gesonde" omgewing noodsaaklik is vir sy voortbestaan, hel aanleiding daartoc gegec dat dic analise van ekologiese risiko soms gelyk gestel word aan menslike gesondheidsrisiko. Daarom word dic begrip "omgewingsgesondheid" dikwels verwarrend gebruik: soms om na die omgewing te verwys in terme van die gesondheidsrisiko's wat dit vir die individu (mens) inhou en soms weer om na die "gesondheid" van die natuur self - optimale funksionering van die ckostelsels - te verwys. Enersyds gaan dit om die gesondheid van individue (die mens) en andersyds om dic instandhouding van die funksic en struktuur van ckostelsels. Natuurlik sal vernictiging van ckostelsels implikasies inhou vir die welvaart van die mensdom.

Aangesien ekostelsels nic organismies van aard is nic, is "gesondheid" nic dic geskikste term om dic toestand daarvan te beskryl nie.' Die dinamiese aard van die stelsels is ingewikkeld en dit mag selfs onmoontlik wees om dic tockoms van ckostelsels akkuraat te voorspel. ${ }^{2}$ Wanneer' $n$ ekostelsel onder druk verkeer, is dic aanname dat dit sal "herstel" madat hicrdic druklaktor, (bv. chemiese besocdeling) verwyder word, nie noodwendig korrek nie. ${ }^{2}$ Dic metaloor van 'n ckostclsel se "gesondheid" is dus nie baie toepaslik in 'n welenskaplike sin nic. Suter' verwerp hicrdic terminologie op grond daarvan dat die stelsel nie organismies is nie en daar nic homeostatiese patrone is wal deur 'n sentrale geneticse kern of enkele "genotipe" bepalal word nie. Ekostelsels verander dus voortdurend en sal nooit na die vorige tocstand terugkecr, volgens hicrdic beskouing nic. Evolusic en dic geskicdenis van spesiasic dui cerder op 'n chatotiese stelsel heide in terme van die getal spesies wat gegenereer word en die koers van spesiasic. Indien die stelsel dus struklureci en funksionecl verander het as gevolg van blootstelling alan 'n langdurige druklaktor is dit hoogs onwaarskynlik dat herstel na dic vorige toestand sal plaasvind.

Dit is dus duidelik dat dic bepaling van impak op ekostclscls nie maklik is nic. Die ckologiese relevansic van 'n chemiese impak is recds deur baic navorscrs ondersock. ${ }^{t-k}$ Daar is algemene aanvaarding dat toksisiteitstoetse in dic laboratorium baic beperkte ekologiese waarde het. Toksikologiese evaluerings moet na hoër vlakke van biologiese organisasic (bevolkings cn gemecnskappe) uitgebrei word om sinvol te wecs. Jepson en Sheratt" en Ferson el al." wys daarop dat dic huiclige stand van ckologiese teoricë vir cvaluerings op gemeenskaps- en ckostclsclvlak nog te gebrekkig is sodal ons grootliks op dic vlak van bevolkings moet konsentrecr.

\section{Effekte van besoedelstowwe op bevolkingsvlak}

Uitgebreide en duur moniteringsprogramme is handig om ' $\mathrm{n}$ idee te gec van dic vlakke en soort besoedeling, maar is waardeloos indien dit nic dic antwoord verskal waarna ons sock nic." Risiko-assessering poog om konsentrasies van toksiesc slowwe te bereken wat as "veilig" beskou kan word vir die voortgesette instandhouding van gemeenskapstruktuur en funksic. Gewoonlik word van laboratoriumtoetse gebruik gemaak en word die anname gemaak dat die sensiliwiteit van spesies 'n sekere matematiese verspreiding (log-normaal of loglogistics) volg." Maar langtermynblootstelling aan toksicsc stowwe kan in die naluur lei lot ellickle soos byvoorbecld verhoogde wecrstand.

Bevolkingstolcransie ${ }^{12.13}$ kan as 'n geskikte parameter beskou word om die nello angepastheid te meet. Toksies-geindusecrde verandering in bevolkingstoleransie implisecr dat 'n mate van natuurlike seleksie plaasgevind het of an dic gang is. Dit is gewoonlik die resultaat van 'n kombinasie van físiologiese aanpassing en genetiese aanpassing. ${ }^{14}$

Dié komplckse aanpassing as 'n cvolusionêre cflek van dic toksiese stol' is reeds vir springsterte gedemonstreer. ${ }^{15,16}$ Verskeic bevolkingseienskappe van weerstandbiedende hevolkings kan verander soos byvoorbecld allosiemfrekwensies en cienskappe van die lewensgeskiedenis." Springstert-bevolkings in metalalbesoedelde gronde het 'n beter ckskresic-doeltrelfentheid vir metale, 'n hoür grocikoers, 'n korler juveniele periode en hulle mortalitcitskoers in skoon toestande is hoër as dic vall kontrolebevolkings. ${ }^{17}$ Daar is ook aanduidings dat erdwurmbevolkings soortgelyke aanpassings kan ondergaan. ${ }^{1 \times}$

Dic alleiding is dat toksiese stow we oor verskeic generasies 
gelykiydig vir verskeic kenmerke selekteer. In die alanvanklike fase van blootstelling kan 'n toename in die toegevoegde genelicse variasic plaasvind as gevolg van ekspressie en frekwensie van "nuwe" gene." Die druk of stress kan die variansie van ienolipiese kenmerke in bevolkings beïnvloed deurdal dit onder andere mulasies kan veroorsaak, die uitdrukking van bestaande gene kan induseer en rekombinasiekoerse kan verhoog. ${ }^{21,12} \mathrm{Op}$ 'n latere stadium kan 'n verlies in variasie intrec ól as gevolg van seleksic ól weens dic sogenaamde bottelnek-clfek. ${ }^{21}$ Toksiese eflekte op die bevolkingsvlak tree skynbaar in wanneer konsentrasies van dic toksiese stof die GWEK (geen waargenome eflek konsentrasie) ${ }^{*}$ oorskrei.

\section{Genetiese veranderinge en toleransie}

Op die gemeenskapsvlak sal toksiese drukliaktore normaalweg lei tot die uitskakeling van die sensiliewe spesies met'n gevolglike verlies aan diversileit. Individuele akklimasie en geneticse aanpassing dra by tot die tolale gemeenskapsweerstand. Bevolkingsresponse op loksiese stowwe in die natuur kan met behulp van verskeie genetiese studies waargeneem word. Allosiemstudies en analise van mitochondriale DNA is voorbeclde van bruikbare metodes wat van beperkıc ckologicse waarde kan wees.

Verskeic navorsers het probeer om die algemene uitwerking van blootstelling aan toksiese stowwe op geneliese variasic te demonstrecr. ${ }^{22.23 .24}$ Allecl frekwensic op lokusse vir algemene, oplosbare ensicme is nic geaffektecr deur blootstelling aan toksiese stowwe nie. Lower ${ }^{29}$ het veranderde allosiemlickwensies by sekere lokusse van die vruglevlieg gevind in 'n besoedelingsgradiënt rondom 'n loodsmeltery. By dic springstert Orchesella cincta het toleransic gekorrelecr met 'n verandering in alleclfrekwensic by die lokus vir glutamaat-oksalo-asetaat. ${ }^{23}$ Murdoch en Herbert ${ }^{26}$ hel miDNA gebruik om veranderinge in genetiese variasie waar te neem in akwatiese bevolkings wat aan besoedelingsdruk onderworpe was. Bevolkings uit besoedclde omgewings het 'n lac genetiese variasie ten opsigte van miDNA gehad in vergelyking met dié uit onbesoedelde omgewings. Shaw ${ }^{27}$ het getoon dat 'n verlies aan geneticse variasic by 10 uit 14 alngepastheidskenmerke by dic mos Funaria hygrometrica kan voorkom.

Dic aanduidings is. hoewel in baic gevalle tentatief. dat bevolkingstoleransie deur middel van genetiese variasic voorkom. ${ }^{8}$ Lewensgeskiedenistcorieë stel dat natuurlike seleksic neig om aangepastheid tc maksimecr deurdat lewensloopkomponente ge-optimeer word. ${ }^{2 k}$ Vir baic organismes om maksimum aangepastheid in stand te hou in 'n gekontaminecrde omgewing beteken dat hulle lewensiklusienotipes binne een generasic moet kan aanpas en sodoende fenotipiese plastisiteit moet toon. Verskuiwings in lewensgeskiedenisse is recds gerapporteer vir houtluisc. ${ }^{30.30 .31}$ Dic omvang van potensiëlc fenotipes wat vir 'n enkele genotiep kan ontwikkel, heet dic reaksienorm. "2 In die natuur bestaan 'n bevolking uit baic verskillende genolipes, elk mel'n spesificke reaksienorm vir sckere drukfaktore. Baird, Barber en Callow ${ }^{33}$ het groot verskille in reaksienorme by verskillende genotipes vall Daphnia aangetoon ten opsigte van toleransic vir kadmium. Dic funksionering van organe en selle kan natuurlik ook beĭnvloed word $\mathrm{en}$ as aanduiders van besocdeling optree sonder dat die fenoliep verander.

Gevoeligheid vir toksiese stowwe kan as die standaardreaksicnorm beskou word. Uitgedruk deur middel van dic klassicke dosis-respons-verhouding vir' 'n enkele genotiep. vertoon die verhouding die fenotipiese plastisiteit van daardie genotiep teenoor die toksiese stol. In die natuur is die besoedelingstof dus net nog 'n druklaklor' soos temperallum; humiditeit, ens. Bradshaw en Hardwick ${ }^{3+}$ meen dat in die geval van 'n drukfakıor wat in tyd en ruimle variecr, sal lenotipiese plastisiteit, ecrder as seleksic ten gunste van dic tolerante genotiep, die meer waarskynlike evolusionêre pad wees wal gevolg word. Gevolglik is die konsekwente gebruik van die GWEK as sou dit ' "veilige" konsentrasic wees, problematies.

\section{Molekulêre antwoordle}

Dit is dus duidelik dat baic antwoorde wat op die bevolkingsvlak nodig is in toenemende mate op die molekulêre vlak gesoek moet word. Molekulêre tegnicke bied kragtige metodes om veranderinge in individue van bevolkings wal alan toksiese slowwe blootgestel is, walar te neem. Dié veranderinge wat in genotieplrekwensies intree as gevolg van toksiese druk op die mikro-evolusionêre vlak, kan mel variansie in bevolkingskenmerke in verband gebring word. Tot dusver is geneliese veranderlikheid nog tot 'n beperkte mate deur ensiempolimorlismes op elektroloreticse jelle alangetoon. ${ }^{23}$ Mulageniese chemikalieë en ioniscrende straling is reeds as oorsake van toenemende veranderlikheid in chromosomale DNA geïdentifiscer. ${ }^{12}$ Parsons ${ }^{35}$ het getuienis gelewer dat de novo-variasic as gevolg van rekombinasies en mutasies kon toeneem onder bepaalde druklaktore. Die soeke na 'n skakel tussen dic impak van 'n kontaminant op die ekostelsel of sy funksionele diversiteit en die chemies-lïsiologiese prosesse op die subsellulêre vlak mag die antwoorde hied op die vraag of so "n effek "ckologics relevant" is. Tegnicke soos die polimerase ketlingreaksies (PKR) mak dit moontlik om klein hoeveclhede DNA te "vergrool". Hierdie en ander tegnieke soos vlocisitometrie lewer inligting oor mutasickoerse wat op toksiese drukfaktore reageer.

Die tocpassing van verskeic biocheniese tegnicke en dic gebruik van biomerkers ${ }^{6} k$ an dien as ecrste, vinnige aanduiders van nadelige ellekte, maar heclwat navorsing is nog nodig om 'n behoorlike ekologiese interpretasie dalaban te heg.

\section{SuMMARY}

Modern socicty is becoming increasingly dependant on chemicals which may enter the natural environment where they may cause damage. Although our analytical ability to qualify and quantify chemicals in the environment is continuously improving, this does not provide answers abou biological availability. It is therefore difficult to define "sale" concentrations of an environmental contaminant. We are primarily interested in determining the ccological implications of a chemical. This has lead to the confusing use of the term "environmental health" to refer both to the "health" of the natural environment or ccosystems as well as to the quality of the environment for human health. Since ecosystems are by nature not organismic and have no central genetic core or "genotype" controlling homeostatic patterns, the metaphor of "environmental health" has no scientific foundation. The dynamic, changing nature of ccosystems may make it impossible to predict the future of ecosystems.

Evolution and the history of speciation points to a chaotic system which will not necessarily return to the previous state once chemical stressors are removed. There is evidence from studics on springtails that populations can undergo physiological and genetic adaptation under conditions of environmental pollution. Various population characteristics of tolerant 
populations can change, such as allozyme frepuency and lifehistory traits. Excretion efficiency for metals can improve and shorter juvenile periods can result. Indications are that carthworms also develop resistance to heavy metals.

At the community level chemical stress can eliminate sensitive species with a resultant loss in bio-diversity. Various researchers have uried to demonstrate effects of chemicall stress on genetic variation. Changes in lile-histories have also been reported lor woodlice.

Many answers to question at the population level are increasingly sought at the molecular level. Molecular techniques can provide useful tools to measure changes in individuals. These changes which are reflected in genotype frequencies can be related to variation in population trats. By linking these, we may come closer to the answer to what constitutes a significant ecological effect. The use of biomarkers are primary and quick ways to show detrimental effects but much more research is required to arrive at ccological interpretations

\section{I.ITERATUURVERWYSINGS}

1. Ferson, S., Ginzburg, L.R., Goldstein, R.A. (1996). Inferring ecological risk from toxicity bioassays, Water Air Soil Poll., 90.7182.

2. Landis, W.G., Ming-Ho Yu. (1995). Introduction to envirommental oxicology: hmpacts of chemicals on ecological systems (Lewis Publishers, London).

3. Suler, G.W. (1993). A critique of ecosystem health coneepts and indexes. Emirom. Toxicol. Chem., 12, 1533-1539.

4. Cairns, J. (1992). Paradigms llossed: the coming of age of environmental toxicology, Emirom. Toxicol. Chem. 11, 285-287.

5. Bartell, S.A., Gardner, R.H., O'Neil, R.V. (1992). Ecological risk estimation. (Lewis Publishers, Floridil).

6. Peakall, D. (1992) Animal biomarkers as pollution indicators (Chapman \& Hall, London).

7. Forbes, V.E., Forbes, T.L. (1994). Ecoroxicology in theory and practice (Chapman \& Hall, London).

8. Posthuma, L. (1997). Effects of toxicants on populations and community paramelers in field conditions, and their potential use in the validation of risk assessment methods. In Ecologial risk assessmem of commaninamts in soil. Van Straalen, N.M., Lokke, H. cds. (Chapmian \& Hall, London).

9. Jepson, P.C., Sheratt, T.N. (1996). The dimensions of space and the assessment of ecotoxicological risks. In Ecoloxicology: Ecological dimensions, Baird, D.J., Maltby, L., Greig-Smilh, P.W., Douben, P.E.T., eds. (Chapman \& Hall, London).

10. Kooijnan, S.A.L.M. (1987). A salety lactor for $\mathrm{LC}_{\mathrm{s}}$ values allowing for differences in sensitivity among specics. Warter Res., 21. 269-276.

II. Kanmenga, J.E., Van Gestel, C.A.M., Bakker, J. (1994). Pallerns of sensitivity to cadmium and pentachlorophenol among nematode species from dilferent taxonomic and ecological groups. Arr/t. Environ. Coutam. Toxicol., 27, 88-94.

12. Forbes, V.E., Depledge, (1996). Environmental stress and the distribution of traits within populations. In Ecotoxicology: Ecological dimensioms. Baird, D.J., Maldby, L.. Greig-Smilh, P.W., Douben, P.E.T. eds. (Chapman \& Hall, London).

13. Luoma..S.N. (1977). Detections of trace contaminamt elfects in aquatic ecosystems, J., Fish Bourd Can., 34, 436-439

14. Klerks, P.L., Weiss, J.S. (1987). Genetic adaptation to healvy metals in aquatic organism: a review, Environ. Pollur., 45, 173-205.

15. Enıst, W.H.O. (1983). Ökologische Anpassungs-stralegien an Böden faktoren. Ber Deutsch. Bol. Ges.. 96, 49-71

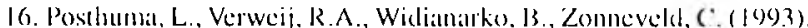
Life-history palterns in metal-adlapted Collembolit. Oikos. 67. 23.5249.

17. Posthuma, L. Hogervorst, R.F., Van Strailen. N.M. (|992), Adaptation to soil pollution by cadmium excerction in netural populations of Orchesella cincta (L.) (Collembola). Arch. Limirm. Comlam. Toxicol. 22, 146-156.

18. Reinecke, S.A., Prinsloo, M.W., Reinecke, A.J. (1999). Resistinneo of kisenia ferida (Oligochacti) 10 cadmium after long-leme exposule: Licotexicol. Einvirom. Safets: (In press)

19. Ilollowily, G.J.. Povey. S.R. Sibly, R.M. (1990)). Evolution in loxin stressed environments, finct. Licol.,,+ 289$)-29+$

20. Hoftmaun, A.A., Parsons. P.A. (199)) Evolutionaly genetics and environmental stress (Oxford University Press. New York)

21. Maruyana. T., Fuerst. P.A. (1985). Populanion boltlenecks and non equilibrium models in population genctics II. The number of alleles in a small population that was formed by a recent bollenteck. Genetics $1 / 1,675-689$.

22. Verkleij, J.A.C., Best-Cramer, W.B., Levering. 11. (1985). Elfect of heavy-metal stress on the genetic structure of populations of Silene

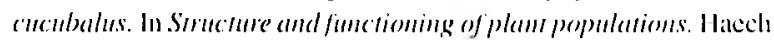
J., Woldandorp, J.W. eds. (North Holland Publi. Amsterdam)

23. Frati, F. Fanciulli, P.P., Posthuma, L. (1992). Allozyme varriation in reference and metal-exposed natural populations of owheselled cincta (lnsecta: Collembola), Biochem. Siwt. Liol. 20, 297-310.

24. Tranvik. L., Sjögren, M., Bengtsson, G. (190 †). Allozymo polymorphism and protein prolite of Orchesella bifacianer (Collembola): indicative of extended metal pollution? Bire hem Sists. Ecol., 22, 13-23.

25. Lower, W.R. (1975). Gene frequency differences in Dresophile melemogeaster associated will lead smelling operations, Murar. Res.. 31,315 .

26. Murdoch, M.H., Herbert, P.D.N. (1994). Milochondrial IDNA diverstiy of brown bullhead from contaminated and relatively pristine sites in the great lakes, Envirm. Toxicol. Chem. 13, 1281-1289.

27. Shaw. J. (1988). Genctic vartiation for tolelance to copper and zinc within and among populations of the moss fimmia hygromentica. New Plytol.. 109, 21।-222

28. Fisher, R.A. (1958). The genetical theory of nitural seleclion. (I over Publishers, New York).

29. Dangerficld. J.M., Hassal. M. (1992). Phenotypic vatriation in the breeding phenology of the woodlouse Armadillidium in/gare. Oecologia, 89, 140-146.

30. Stibor, H. (1992). Predator induced life-histoy shifts in a freshwater cladoccran, Oecologia. 92. 162-165.

31. Woltereck, R. 1909 Weitere experimentale untersuchungen ïber Arlverianderung, speziel über das Wesen quamtitativer Arlunderscheide bei Daphniden, Ver: Dealsch. Zool. Gesell. 1909. 110-172

32. Kamenga, J.E., Kordhals, G.W., Borgers. T., Bakker. J. (1997) Reaction norms for life-history traits as the basis for the evaluation of critical ellect levels of toxicants. In Ecological risk assessmem of contaminams in soil, Van Stratalen. N.M.. Lokke. II eds. (Chapminn \& Hall. London).

33. Baird, D. J., Barber, 1., Callow. P. (1990). Clonal valtiattion in general

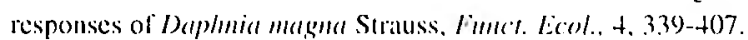

34. Bradshaw, A.D., Hardwick. K. (1989). Evolution and stress genolype and phenotypic components, Bisl. I. I.im. Sirc.. 37. 137 15.5.

35. Parsons, P.A., (1989). Environmental stresses and conservittion of natural populations, Amm. Reve Licol Sist. 20, 29-49.

36. Eijsackers, H. (1997). Soil ecoloxicology: still new wilys to explore or just paving the road? In Ecological risk assessmemt of comtemintunts in soil, Van Stratalen, N.M., Lokke, H. eds. (Chapman \& Hall, London). 